\title{
A bromeliad species reveals invasive ant presence in urban areas of French Guiana
}

\author{
Stanislas Talaga ${ }^{\mathrm{a}, *}$, Jacques H.C. Delabie ${ }^{\mathrm{b}}$, Olivier Dézerald ${ }^{\mathrm{a}}$, Alex Salas-Lopez ${ }^{\mathrm{a}}$, \\ Frédéric Petitclerc ${ }^{\mathrm{a}}$, Céline Leroy ${ }^{\mathrm{c}}$, Bruno Hérault ${ }^{\mathrm{d}}$, Régis Céréghino ${ }^{\mathrm{e}, \mathrm{f}}$, Alain Dejean ${ }^{\mathrm{a}, \mathrm{e}, \mathrm{f}}$ \\ a CNRS, Écologie des Forêts de Guyane (UMR-CNRS 8172), Campus agronomique, BP 316, 97387 Kourou cedex, France \\ ${ }^{\mathrm{b}}$ U.P.A. Laboratório de Mirmecologia, Convênio UESC/CEPLAC, C.P. 7, 45600-970 Itabuna, Bahia, Brazil \\ ' IRD, UMR AMAP (botAnique et bioinforMatique de l'Architecture des Plantes), Boulevard de la Lironde, TA A-51/PS2, F-34398 Montpellier Cedex 5, France \\ 'CIRAD, Écologie des Forêts de Guyane (UMR-CIRAD 93), Campus agronomique, BP 316, 97387 Kourou cedex, France \\ e Université de Toulouse, UPS, INP, Laboratoire Ecologie Fonctionnelle et Environnement, 118 route de Narbonne, 31062 Toulouse, France \\ ${ }^{\mathrm{f}}$ CNRS, Ecolab (UMR-CNRS 5245), 118 Route de Narbonne, 31062 Toulouse, France
}

\section{A R T I C L E I N F O}

\section{Article history:}

Received 29 November 2014

Received in revised form 18 March 2015

Accepted 11 May 2015

\section{Keywords:}

Aechmea aquilega

Bioindicators

Non-specific ant-plant relationships

Surrogacy

Tank bromeliads

Urban ecology

\begin{abstract}
A B S T R A C T
Tank bromeliads, frequently associated with ants, are considered 'biodiversity amplifiers' for both aquatic and terrestrial organisms, and thus have a high ecological value. The focal species of this study, Aechmea aquilega, sheltered the colonies of 12 ant species in a Guianese rural habitat where Odontomachus haematodus, associated with $60 \%$ of these plants, was the most frequent. Unexpectedly, the ant species richness was higher in a compared urban habitat with 21 species, but two synanthropic and four invasive ants were noted among them. Consequently, we conducted baiting surveys (on the ground, on trees and on trees bearing $A$. aquilega) as well as complementary surveys using different sampling modes in urban areas to test if $A$. aquilega is a surrogate revealing the presence of certain invasive ants. During the baiting survey, we recorded four Neotropical and eight introduced invasive ants out of a total of 69 species. Of these 12 invasive species, five were noted by baiting A. aquilega (including two only noted in this way). A bootstrap simulation permitted us to conclude that $A$. aquilega significantly concentrates certain species of invasive ants. This was confirmed by complementary surveys, where we did not record further species. We conclude that baiting on trees bearing large epiphytes in human-modified, Neotropical areas is a relevant complement to the early detection of invasive ants.
\end{abstract}

(c) 2015 Elsevier Ltd. All rights reserved.

\section{Introduction}

Global trade has greatly contributed to the dispersal of plants and animals whose introduction into new habitats generally results in their death or a low rate of survival as they are unable to adapt. Still, some of them have become invasive, constituting an important threat to biodiversity in their introduced range because they can eliminate native species through resource pre-emption and/or direct competition, and, so, disrupt ecosystem functions. This has economic repercussions due to the costs of control measures (Clavero and Garcia-Berthou, 2005; Shogren and Tschirhart, 2005).

Ants are among the most widespread and harmful invasive taxa because they occupy a central place in the functioning of

\footnotetext{
* Corresponding author. Tel.: +33 5945943206 43; fax: +33 594594356522 . E-mail address: stantalaga@free.fr (S. Talaga).
}

ecosystems. This is due to their abundance as they constitute one of the largest fractions of the animal biomass and play different roles in food webs since they can be herbivores, generalists, scavengers or predators. In natural conditions, ants coexist in well-organized communities regulated by competition and predation at both the intra- and inter-specific level. Yet, among invasive ants, so-called 'unicolonial species' form spatially vast and competitively dominant supercolonies over large geographical distances (Holway et al., 2002; Moffett, 2012). Thanks to their huge colonies, they lower the species richness and abundance of native ants through exploitation and interference competition so that they can disrupt the arthropod community structure with subsequent repercussions on the entire ecosystem (Holway et al., 2002).

Therefore, a major challenge is to develop predictive management strategies based on understanding the processes behind these invasions. The period just following the introduction of a potentially invasive species is central to that understanding. This is particularly true for insects which, due to their small size, are 
difficult to detect, so that their presence is generally discovered once the invasive process is already well underway or completed. Because most invasive taxa, including ants, are first introduced into urban areas through maritime harbors or airports and along roads (Holway et al., 2002; Laurance et al., 2009), the early detection of ants in cities is a critical component of environmental management. Yet, the ecological requirements of some potentially invasive ants means that their occurrence can be missed when researchers use a conventional sampling technique, especially when these ants first congregate in certain habitats where, in fact, they can be likened to the 'Trojan Horse'.

Because epiphytes abound in the trees that grow in some Neotropical cities and because epiphytes favor the installation of numerous ant species (Davidson and Epstein, 1989; Dejean et al., 1995; Blüthgen et al., 2000), we hypothesized that large epiphytic plants which commonly form habitats for insects can be "surrogates" for the occurrence of invasive ants prior to their spread. "Surrogacy", or how easily recorded taxa predict the presence of other taxa, can constitute a useful tool in conservation planning (Warman et al., 2004) and could also be used to detect the recent introduction of potentially invasive ants (see also Addison and Samways, 2006, for artificial surrogate habitats).

Tank bromeliads (Bromeliaceae) are flowering plants comprised of 59 genera and some 3140 species native mainly to the Neotropics (Givnish et al., 2011). The interlocking leaves of tank bromeliads form wells that collect rainwater (from a few milliliters to a few liters), leaf litter and other organic detritus. The rosettes of these plants permit numerous opportunistic ant species to profit from the moist habitat. Most ant-bromeliad associations are not speciesspecific (Blüthgen et al., 2000), but specialized associations do exist (Dejean et al., 1995). In this context, the aim of this study was to evaluate whether tank bromeliads can reveal ant invasions in Neotropical cities. Tank bromeliads are frequently found in humanmodified, Neotropical areas, particularly when those areas are close to the seaside, rivers, or lakes, or situated at high, humid altitudes (Richardson et al., 2000; Serramo Lopez et al., 2009; Cach-Pérez et al., 2013; here Aechmea aquilega). So, we first sought to assess whether they point to the presence of synanthropic and invasive ants in urbanized areas of French Guiana, all situated along the coast. Second, we determined if these ant species are outcompeted by native species in a surrounding rural area. Third, we looked for new approaches permitting us to improve the conventional baiting sampling technique so as to detect as effectively as possible the presence of invasive ants by extending the survey to include trees, particularly those bearing an A. aquilega cluster. Further surveys using different sampling techniques rounded out this approach.

\section{Materials and methods}

\subsection{The focal taxa}

A. aquilega, found from Costa Rica to Brazil, usually forms massive clumps of epiphytes on old trees, but can also grow as a geophyte. This large species $(60-120-\mathrm{cm}$ in height; Mori et al., 1997) has tightly interlocking leaves that form a highly compartmented rosette creating a tank (or phytotelm) that collects water and organic detritus and provides a habitat for aquatic micro- and macro-organisms (Carrias et al., 2014).

\subsection{Study areas and field surveys}

\subsubsection{Ants associated with A. aquilega}

Between 2011 and 2013, we studied the ants associated with 45 mature $A$. aquilega in an urban area (each randomly selected in a city block of Sinnamary, French Guiana; $05^{\circ} 22^{\prime} 39^{\prime \prime} \mathrm{N} 52^{\circ} 57^{\prime} 35^{\prime \prime} \mathrm{W}$ ), and
26 others in a rural habitat situated $5 \mathrm{~km}$ away, along $6 \mathrm{~km}$ of a dirt road (route de l'Anse) lined with 10-30 m-tall trees. In both areas, $A$. aquilega abound as epiphytes, with most individuals growing at a height of 3-6 $\mathrm{m}$ on different tree species. The sampling area in each environment extended over a surface of $c a .45$ ha.

We used a ladder to reach the selected $A$. aquilega individuals and removed them from their substrates using a hack saw and then placed each of them into a plastic bag which was sealed to avoid contamination during transport to the laboratory. There, each individual was carefully inspected and taken apart; each leaf was torn from the base starting from the outermost leaf and working inward, allowing us to collect entire ant colonies installed between the leaves among the detritus accumulated by the plant.

\subsubsection{Baiting survey to test if A. aquilega is a surrogate helpful in detecting invasive ants}

To detect as effectively as possible the presence of invasive ants, we used a conventional sampling technique consisting of baiting ants with, each time, a series of two 2-ml Eppendorf colorless microtubes (one containing pieces of cotton imbibed with diluted honey and the other containing pieces of canned sardines in oil). Each time, after 30 and then $60 \mathrm{~min}$, the ants occupying the baits and those patrolling all around were collected using an aspirator.

The survey was conducted in Cayenne $\left(4^{\circ} 55^{\prime} 59^{\prime \prime} \mathrm{N} ; 52^{\circ} 19^{\prime}\right.$ $\left.59^{\prime \prime} \mathrm{W}\right)$, Kourou $\left(05^{\circ} 09^{\prime} 30^{\prime \prime} \mathrm{N} ; 52^{\circ} 38^{\prime} 34^{\prime \prime} \mathrm{W}\right)$ and Sinnamary, three cities in the littoral zone of French Guiana (white sand deposits) and situated along a river. Less than $95 \mathrm{~km}$ (as the crow flies) separate Cayenne from Sinnamary, with Kourou located almost midway. First, we placed 30 pairs of baits on the ground separated by an interval of more than $20 \mathrm{~m}$ in Cayenne (the airport; the heliport; the tarmac of the harbor; the marina; and at the base of the building of the Customs Office in the harbor), in different city blocks of the Vieux Bourg of Kourou (areas not far from the marina) and Sinnamary (in different city blocks; more than $100 \mathrm{~m}$ from each other). Second, in Kourou and Sinnamary, we used the same type of sampling technique, placing the baits at more than $2 \mathrm{~m}$ in height on the trunks of 30 tall trees ( $>15 \mathrm{~m}$ ), mostly mango (Mangifera indica) and mombin (Spondias mombin), both Anacardiaceae, and Inga spp. (Mimosoideae). These trees were chosen haphazardly in different city blocks. Third, to verify the ability of $A$. aquilega to concentrate invasive ant species, the same survey was conducted in Sinnamary on 30 other large trees bearing an A. aquilega cluster (almost all were mango trees) and situated in different city blocks than the previous trees or in different distant parcels of the same block (with a distance of more than $75 \mathrm{~m}$ between two trees). A complementary survey was conducted in the three cities. We firstly prospected by sight along the grassy roadsides of different city blocks, totalizing in each city more than $5 \mathrm{~km}$. Only the workers of infrequent species were gathered (using an aspirator) for further identification. Second, we sampled ants from 20 plots $\left(6 \mathrm{~m} \times 3 \mathrm{~m} ; 18 \mathrm{~m}^{2}\right)$ situated in grassy areas in different city blocks. Sampling was standardized by spending one man-hour per plot carefully searching for ants in all suitable microhabitats: the leaf litter including all hollow, rotten twigs; dead wood; humus and the bare ground. Third, we conducted a baiting survey on trees smaller than in the previous survey (i.e., 5-12 m in height). Also, in the Vieux Bourg in Kourou, we baited the only nine reachable mango trees bearing an A. aquilega cluster.

Voucher specimens of the ants were identified and deposited in the Laboratório de Mirmecologia collection (acronym: CPDC), Cocoa Research Centre (Ilhéus, Bahia, Brazil).

\subsection{Statistical comparisons}

We compared the ant diversity in the two habitats using Shannon's diversity t-test (PaST software; diversity statistics), and the 


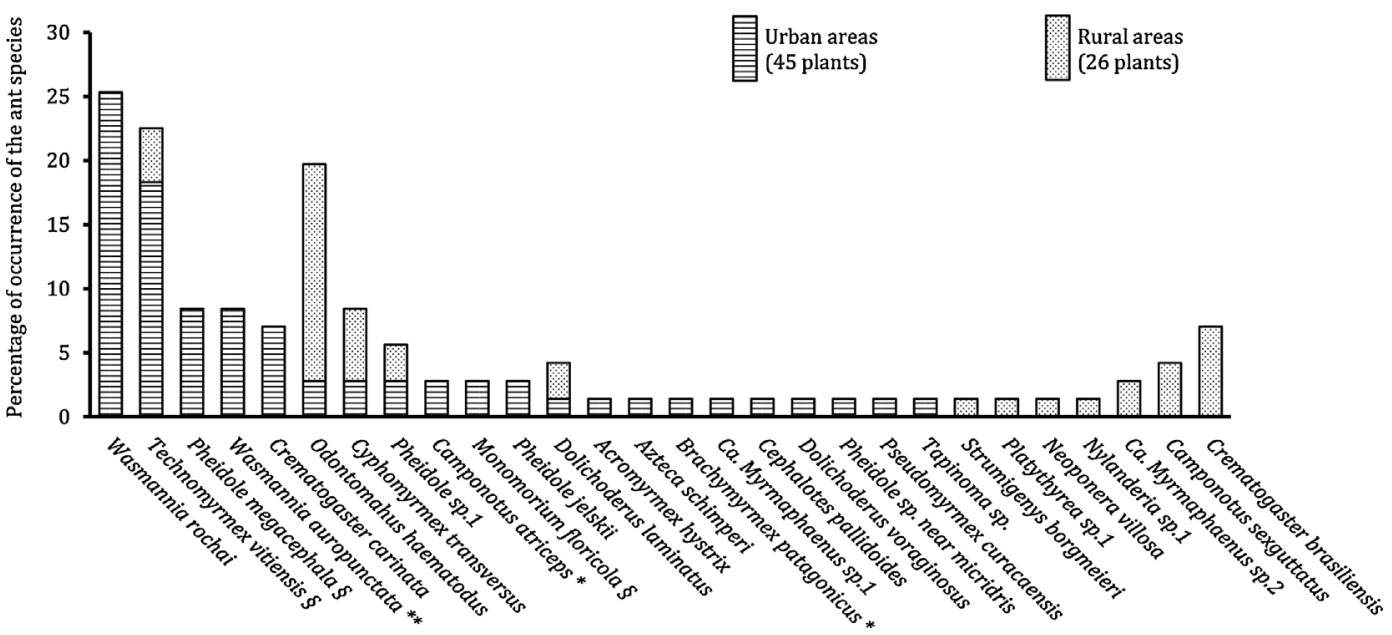

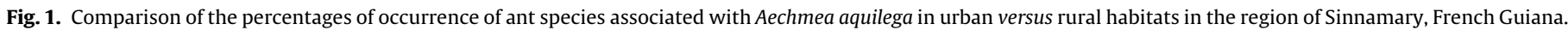
*: synanthropic species; $\S$ : introduced invasive species; ${ }^{* *}$ : Neotropical invasive species.

ant communities using the Permutational Multivariate Analysis of Variance (PERMANOVA; R software; R Development Core Team, 2013).

The aim of the baiting survey was to test the relative contribution of each of the 10 baiting situations to the total number of invasive ant species recorded in the area. Using $\mathrm{R}$ software, we conducted a bootstrap simulation where we "sampled" with replacements the 10 baiting situations. From these simulations, we counted the number of species, and the procedure was repeated 10,000 times. We then split the 10,000 simulations into two groups, one where the A. aquilega situation was sampled at least once and a second where it was not sampled at all. Finally, we tested the differences in species number between these two groups with a non-parametric Wilcoxon rank sum test with the continuity correction.

\section{Results}

3.1. Comparing the ant fauna associated with $\mathrm{A}$. aquilega between a rural and an urban area

In all cases, we noted the presence of ants between the base of the A. aquilega and the bark of the host trees. A total of 56 out of the 71 A. aquilega sampled (79\%) sheltered, between their leaves, ant colonies belonging to 28 species and five subfamilies (Fig. 1 and Supplementary Appendix A).

A comparison of the percentages of occurrence of these ant species illustrated the difference in their distribution between the rural and urban areas (12 versus 21 species, respectively; Fig. 1). Indeed, the difference in ant species richness was significant (Shannon's diversity $t$-test: $t=3.66$; $\mathrm{df}=280 ; P=0.0003$ ) and the ant assemblages were significantly different between the two sites (PERMANOVA: $N=54 ; F=15.05 ; P=0.0001$ ).

Odontomachus haematodus was by far the most frequent species in the rural area where it occupied $60 \%$ of all of the sampled plants sheltering ants. We noted that elementary nests (the colonies are composed of multiple nests) of this species were installed both between the leaves of several adjacent $A$. aquilega individuals and between their shoots and the bark of the host trees.

\subsection{Baiting survey to test if A. aquilega is a surrogate helpful in detecting invasive ants}

During the baiting survey, we recorded 69 ant species, including 12 well known invasive species, four of which are Neotropical and are invasive in human-disturbed areas of their native range and elsewhere where they were introduced through human transport; the eight others were introduced (Table 1 and Supplementary Appendix A). Among the introduced invasive ants, five species were recorded during baiting on the ground (i.e., Monomorium floricola; Paratrechina longicornis; Tapinoma melanocephalum; Tetramorium lanuginosum; and Tetramorium simillimum); two of them, M. floricola and Ta. melanocephalum, were also recorded on trees. Cardiocondyla obscurior was only detected through baiting on trees, and two more species, Pheidole megacephala and Technomyrmex vitiensis, only by baiting on trees bearing an A. aquilega cluster; the latter trees sheltered five invasive species, four of them introduced (Table 1).

Furthermore, the probability of detecting an introduced invasive ant species was particularly high on trees bearing an A. aquilega cluster compared to the other situations. Each time the "A. aquilega situation" was included in the simulated sample, the number of invasive species was significantly higher than simulations where the "A. aquilega situation" was not included (Fig. 2; Wilcoxon rank sum test: $W=2,251,583 ; N=10,000 ; P<2.2 \mathrm{e}-16$ ).

The complementary survey permitted us to again note $\mathrm{Pa}$. longicornis and Ta. melanocephalum among the introduced invasive ants, plus a tramp species, Cardiocondyla wroughtoni (Seifert, 2003).

\section{Discussion}

4.1. Comparing the ant fauna associated with A. aquilega between a rural and an urban area

Overall, one can note a convergence between the ant assemblage found in the rural area studied and that of Venezuelan tank bromeliads (Fig. 1; Blüthgen et al., 2000) as 0 . haematodus was the most frequent species, Cyphomyrmex spp. abounded, and Dolichoderus laminatus, Neoponera villosa, and species of the genera Nylanderia, Pheidole and Platythyrea were also recorded. The dominance of $O$. haematodus is reminiscent of the $N$. villosa association with Aechmea bracteata in Mexico (Dejean, 1990). Because these two ponerine ant species can also nest in rotten logs or branches lying on the ground, a convergence likely exists where a kind of "local tradition" causes the queens to select these bromeliads as nesting sites. This type of local tradition has also been noted in Odontomachus hastatus and social wasps (Wenzel, 1996; Dejean et al., 1998; Gibernau et al., 2007), experimental studies having shown that such host plant selection is related to an imprinting process (Djiéto-Lordon and Dejean, 1999). 
Table 1

Comparison of ant species recorded in three French Guianese cities using baits ( 30 pairs of baits each time). *: synanthropic species; $\ddagger$ : introduced tramp species (not invasive); $\S$ : introduced invasive species; ${ }^{* *}$ : Neotropical invasive species; \#: two associated ant species (parabiosis) which build ant-gardens containing several epiphytes, including the tank bromeliad Aechmea mertensii; $\uparrow$ : baits on trees bearing Aechmea aquilega in Kourou; total: 69 ant species.

\begin{tabular}{|c|c|c|c|c|c|c|c|c|c|c|}
\hline \multirow[b]{2}{*}{ Ant species } & \multicolumn{7}{|c|}{ Baiting on the ground ( 210 cases) } & \multicolumn{3}{|c|}{ Baiting on trees (90 cases) } \\
\hline & $\begin{array}{l}\text { Cayenne } \\
\text { harbor }\end{array}$ & $\begin{array}{l}\text { Cayenne } \\
\text { heliport }\end{array}$ & $\begin{array}{c}\text { Cayenne } \\
\text { marina }\end{array}$ & $\begin{array}{c}\text { Cayenne } \\
\text { airport }\end{array}$ & $\begin{array}{l}\text { Cayenne } \\
\text { customs }\end{array}$ & $\begin{array}{c}\text { Kourou } \\
\text { city }\end{array}$ & $\begin{array}{c}\text { Sinnamary } \\
\text { city }\end{array}$ & $\begin{array}{c}\text { Kourou } \\
\text { trees }\end{array}$ & $\begin{array}{c}\text { Sinnamary } \\
\text { trees }\end{array}$ & $\dagger$ A. aquilega \\
\hline Azteca cf. chartifex & 0 & 0 & 0 & 0 & 1 & 0 & 0 & 0 & 0 & 1 \\
\hline Azteca instabilis & 0 & 0 & 0 & 0 & 0 & 0 & 0 & 0 & 1 & 0 \\
\hline Azteca schimperi & 0 & 0 & 0 & 0 & 0 & 0 & 0 & 0 & 0 & 1 \\
\hline Azteca sp.1 & 0 & 0 & 0 & 0 & 0 & 0 & 0 & 0 & 1 & 0 \\
\hline Brachymyrmex patagonicus* & 0 & 1 & 1 & 0 & 1 & 1 & 1 & 0 & 0 & 1 \\
\hline Brachymyrmex sp.1 & 0 & 0 & 0 & 0 & 0 & 0 & 0 & 0 & 1 & 0 \\
\hline Camponotus atriceps* & 0 & 0 & 0 & 0 & 0 & 0 & 0 & 0 & 1 & 1 \\
\hline Camponotus blandus & 0 & 1 & 1 & 0 & 1 & 0 & 1 & 0 & 0 & 0 \\
\hline Camponotus crassus & 0 & 0 & 0 & 0 & 0 & 0 & 0 & 1 & 1 & 1 \\
\hline Camponotus fastigatus & 0 & 1 & 0 & 0 & 0 & 0 & 0 & 1 & 0 & 0 \\
\hline Camponotus femoratus\# & 0 & 0 & 0 & 0 & 0 & 0 & 0 & 0 & 0 & $\mathbf{1}$ \\
\hline $\begin{array}{l}\text { Camponotus (Myrmaph). sp. } \\
1\end{array}$ & 0 & 0 & 0 & 0 & 0 & 0 & 0 & 0 & 1 & 1 \\
\hline Camponotus melanoticus & 0 & 0 & 0 & 0 & 0 & 1 & 1 & 0 & 0 & 0 \\
\hline Camponotus renggeri & 0 & 0 & 0 & 0 & 0 & 0 & 0 & 0 & 1 & 0 \\
\hline Camponotus rufipes & 0 & 0 & 0 & 0 & 0 & 1 & 1 & 1 & 0 & 0 \\
\hline Camponotus senex & 0 & 0 & 0 & 0 & 0 & 1 & 0 & 0 & 0 & 0 \\
\hline Camponotus sexguttatus* & 0 & 0 & 0 & 0 & 1 & 0 & 0 & 1 & 0 & 0 \\
\hline Cardiocondyla minutior $\ddagger$ & 0 & 0 & 1 & 0 & 0 & 0 & 1 & 1 & 0 & 0 \\
\hline Cardiocondyla obscurior§ & 0 & 0 & 0 & 0 & 0 & 0 & 0 & 1 & 0 & 0 \\
\hline Cephalotes pallidoides & 0 & 0 & 0 & 0 & 0 & 0 & 0 & 1 & 0 & 1 \\
\hline Cephalotes sp. 1 & 0 & 0 & 0 & 0 & 0 & 0 & 0 & 0 & 1 & 0 \\
\hline Crematogaster abstinens & 0 & 0 & 1 & 1 & 0 & 1 & 0 & 1 & 0 & 0 \\
\hline Crematogaster carinata & 0 & 0 & 1 & 0 & 0 & 0 & 0 & 0 & 1 & 1 \\
\hline Crematogaster curvispinosa & 0 & 0 & 0 & 0 & 0 & 0 & 0 & 1 & 0 & 0 \\
\hline Crematogaster erecta & 0 & 0 & 0 & 0 & 0 & 0 & 0 & 1 & 0 & 0 \\
\hline Crematogaster levior\# & 0 & 0 & 0 & 0 & 0 & 0 & 0 & 0 & 0 & 1 \\
\hline Crematogaster sp.1 & 0 & 0 & 0 & 0 & 0 & 0 & 0 & 0 & 1 & 0 \\
\hline Crematogaster tenuicula & 0 & 0 & 0 & 0 & 0 & 0 & 1 & 0 & 0 & 0 \\
\hline Cyphomyrmex transversus & 0 & 0 & 0 & 0 & 0 & 0 & 0 & 0 & 0 & 1 \\
\hline Daceton armigerum & 0 & 0 & 0 & 0 & 0 & 0 & 0 & 0 & 1 & 0 \\
\hline Dolichoderus laminatus & 0 & 0 & 0 & 0 & 0 & 0 & 0 & 0 & 0 & 1 \\
\hline Dolichoderus voraginosus & 0 & 0 & 0 & 0 & 0 & 0 & 0 & 0 & 0 & 1 \\
\hline Dorymyrmex brunneus* & 0 & 0 & 0 & 0 & 0 & 1 & 1 & 0 & 0 & 0 \\
\hline Dorymyrmex pyramicus* & 0 & 0 & 0 & 0 & 0 & 1 & 1 & 0 & 0 & 0 \\
\hline Ectatomma brunneum* & 0 & 0 & 0 & 1 & 0 & 0 & 1 & 0 & 0 & 0 \\
\hline Monomorium floricola $\$$ & 0 & 0 & 1 & 0 & 1 & 0 & 0 & 1 & 0 & 1 \\
\hline Neoponera villosa & 0 & 0 & 0 & 0 & 0 & 0 & 0 & 0 & 0 & 1 \\
\hline Nylanderia fulva** & 0 & 0 & 1 & 1 & 0 & 0 & 0 & 0 & 0 & 0 \\
\hline Nylanderiasp.1 & 0 & 0 & 0 & 0 & 0 & 0 & 1 & 0 & 1 & 0 \\
\hline Odontomachus haematodus* & 0 & 0 & 0 & 0 & 0 & 0 & 1 & 1 & 0 & 1 \\
\hline Paratrechina longicornis $\S$ & 1 & 1 & 1 & 1 & 1 & 0 & 1 & 0 & 0 & 0 \\
\hline Pheidole fallax* & 1 & 1 & 1 & 1 & 1 & 1 & 1 & 0 & 0 & 0 \\
\hline Pheidole Diligens group sp. & 0 & 0 & 1 & 0 & 0 & 0 & 0 & 0 & 0 & 0 \\
\hline Pheidole jelskii* & 0 & 0 & 0 & 0 & 0 & 1 & 1 & 0 & 0 & 0 \\
\hline Pheidole megacephala§ & 0 & 0 & 0 & 0 & 0 & 0 & 0 & 0 & 0 & 1 \\
\hline Pheidole cf. micridris & 0 & 0 & 0 & 0 & 0 & 0 & 0 & 0 & 0 & 1 \\
\hline Pheidole radoszkowskii & 0 & 0 & 0 & 0 & 0 & 1 & 1 & 0 & 0 & 0 \\
\hline Pheidole Flavens group sp.1 & 0 & 0 & 0 & 0 & 0 & 1 & 1 & 1 & 0 & 1 \\
\hline Pheidole Flavens group sp. 2 & 0 & 0 & 0 & 0 & 0 & 0 & 0 & 1 & 1 & 1 \\
\hline Pheidole sp. 3 & 0 & 0 & 0 & 0 & 0 & 0 & 0 & 0 & 1 & 0 \\
\hline Pheidole synamarta & 0 & 0 & 0 & 1 & 0 & 0 & 0 & 0 & 0 & 0 \\
\hline Platythyrea sinuata & 0 & 0 & 0 & 0 & 0 & 0 & 0 & 0 & $\mathbf{1}$ & 0 \\
\hline Pseudomyrmex curacaensis & 0 & 0 & 0 & 0 & 0 & 0 & 0 & 0 & 1 & 1 \\
\hline Pseudomyrmex gracilis & 0 & 0 & 0 & 0 & 0 & 1 & 0 & 1 & 1 & 1 \\
\hline Pseudomyrmex oculatus & 0 & 0 & 0 & 0 & 0 & 0 & 0 & 0 & $\mathbf{1}$ & 0 \\
\hline Pseudomyrmex simplex & 0 & 0 & 0 & 0 & 0 & 0 & 0 & 0 & 1 & 0 \\
\hline Pseudomyrmex sp.1 & 0 & 0 & 0 & 0 & 0 & 0 & 0 & 0 & 1 & 0 \\
\hline Pseudomyrmex termitarius & 0 & 1 & 0 & 0 & 0 & 1 & 1 & 0 & 0 & 0 \\
\hline Solenopsis (Diplorhopt.) sp. & 0 & 0 & 0 & 0 & 0 & 0 & 0 & 0 & 0 & 1 \\
\hline Solenopsis geminata** & 0 & 0 & 1 & 0 & 0 & 0 & 1 & 0 & 0 & 0 \\
\hline Solenopsis globularia* & 0 & 1 & 0 & 1 & 1 & 1 & 0 & 0 & 0 & 0 \\
\hline Solenopsis saevissima** & 1 & 1 & 1 & 1 & 1 & 1 & 1 & 0 & 0 & 0 \\
\hline Tapinoma melanocephalum§ & 0 & 0 & 1 & 0 & 0 & 0 & 1 & 0 & 1 & 1 \\
\hline Tapinoma sp.1 & 0 & 0 & 0 & 0 & 0 & 0 & 0 & 1 & 1 & 1 \\
\hline Technomyrmex vitiensis & 0 & 0 & 0 & 0 & 0 & 0 & 0 & 0 & 0 & 1 \\
\hline Tetramorium lanuginosum $\S$ & 0 & 0 & 0 & 0 & 1 & 0 & 0 & 1 & 0 & 0 \\
\hline Tetramorium simillimum $\S$ & 0 & 0 & 0 & 0 & 0 & 1 & 0 & 0 & 0 & 0 \\
\hline Wasmannia auropunctata** & 0 & 0 & 0 & 0 & 0 & 0 & 1 & 1 & 0 & 1 \\
\hline Wasmannia rochai & 0 & 1 & 0 & 1 & 0 & 0 & 0 & 1 & 0 & 1 \\
\hline No. of species & 3 & 9 & 13 & 9 & 10 & 16 & 22 & 19 & 22 & 28 \\
\hline Total No. of invasive species & 2 & 2 & 6 & 3 & 4 & 2 & 5 & 4 & 1 & 5 \\
\hline $\begin{array}{l}\text { No. of introduced invasive } \\
\text { species }\end{array}$ & 1 & 1 & 3 & 1 & 3 & 1 & 2 & 3 & 1 & 4 \\
\hline
\end{tabular}




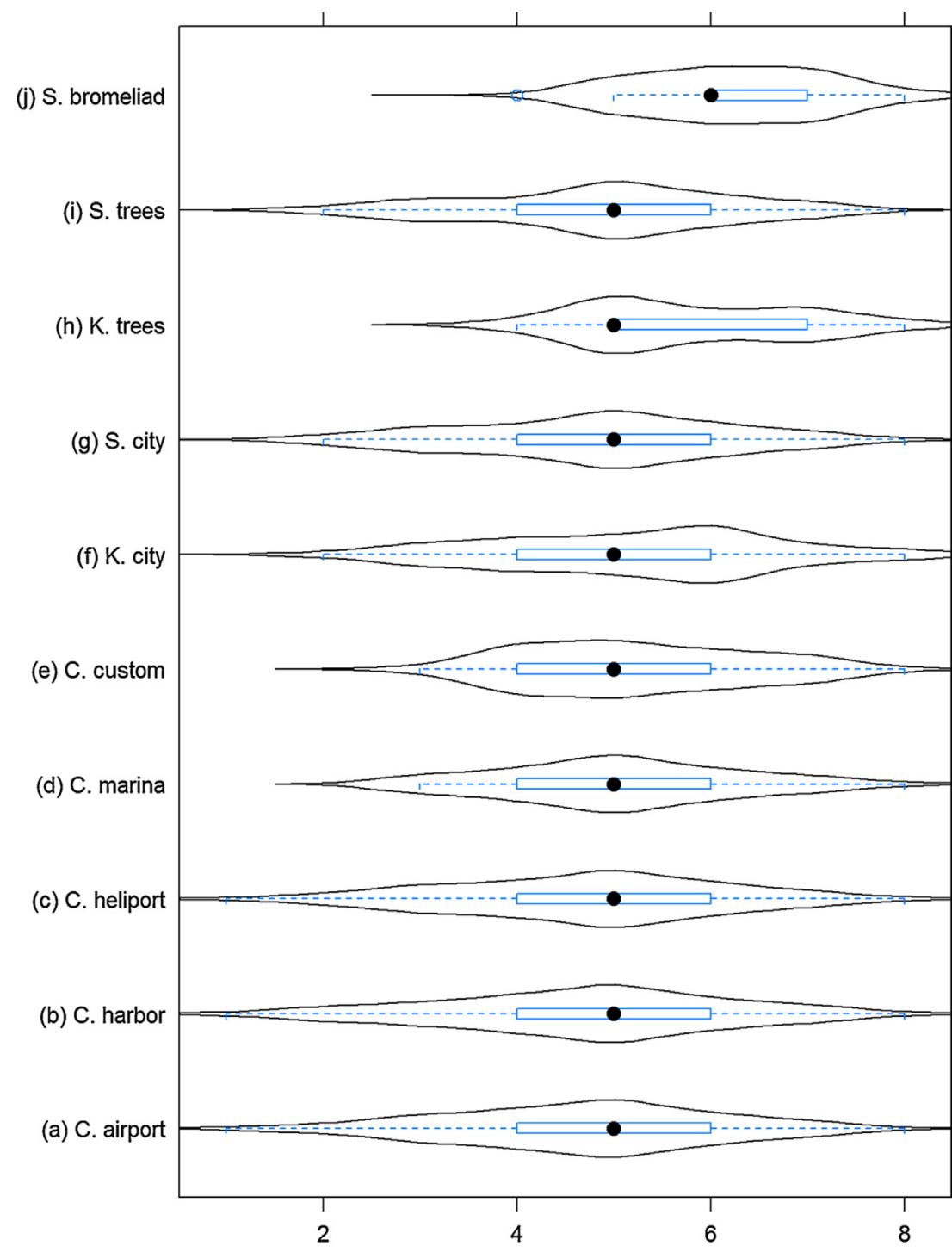

Number of Invasive Species

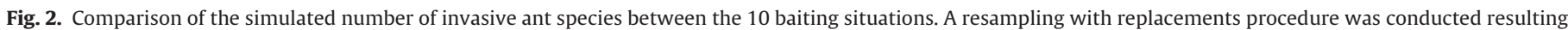

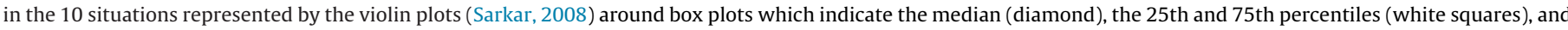

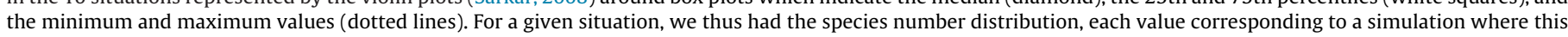

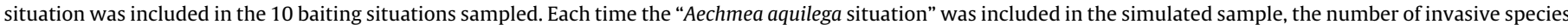

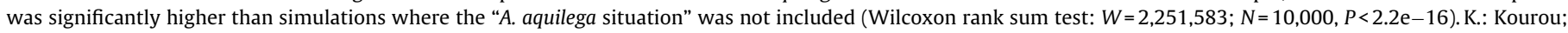
C.: Cayenne; S.: Sinnamary; bromeliad: trees bearing an A. aquilega bromeliad: large trees sheltering Aechmea aquilega clusters.

The much lower level of 0 . haematodus occurrence in the urban area is likely due to anthropogenic disturbances which placed native ants at a disadvantage while favoring synanthropic species, particularly invasive species (Fig. 1 and Supplementary Appendix A). The latter likely lowered native ant richness and abundance through exploitation and interference competition (see Holway et al., 2002). Note that 0 . haematodus colonies, as was observed here, can develop in cities, even nesting in wall crevices or under flower pots (Delabie et al., 1995). Also, this ant species was recently introduced into the Gulf Coast of the USA (MacGown et al., 2014). Note that in the rural area only Tec. vitiensis was recorded as an A. aquilega associate among the known invasive ants, indicating the beginning of a possible spread.

Three of the species recorded, namely Wasmannia auropunctata (Neotropical), Tec. vitiensis and Ph. megacephala (both of which are introduced species), are invasive ants particularly known for their negative ecological and agricultural impact (Holway et al., 2002; Bolton, 2007; Delabie et al., 2011; Wetterer, 2012).

\subsection{Baiting survey}

First, ground baiting permitted us to gather four invasive Neotropical species. Wasmannia auropunctata is invasive in many tropical areas where it was introduced; this species, also noted during baiting on trees including those bearing A. aquilega, is known to spread in human-disturbed areas of its native range where it can displace other ants (Orivel et al., 2009). Nylanderia fulva, a Formicinae native to South America, has invaded the southern USA where it is capable of detoxifying the venom of the introduced fire-ant, Solenopsis invicta (LeBrun et al., 2014). Native to Central and South America, Solenopsis geminata is now widespread in the Tropics (Holway et al., 2002). Also, Solenopsis saevissima, with supercolonies extending over dozens of kilometers, has 
negative ecological impacts and has been noted outside its native range (Taber, 2000; Wetterer, 2014a; Lenoir et al., 2015).

Second, during ground baiting, we recorded the five following introduced invasive species. Monomorium floricola, also noted on trees including those bearing A. aquilega, is a widespread arboreal species native to tropical Asia which can be a house pest (Wetterer, 2010a) or affect the structure of arboreal ant assemblages (Conceição et al., 2014). Paratrechina longicornis and Ta. melanocephalum (the latter was also noted on trees bearing A. aquilega), which have spread worldwide including into cold regions due to their ability to live in houses, are native to the Old World Tropics (Wetterer, 2008, 2009). Tetramorium lanuginosum, which was also noted on trees, and Tet. simillimum are widespread invasive species, the former is native to tropical East Asia, the latter to Africa (Wetterer and Wetterer, 2004; Wetterer, 2010b). This is the first report of Tet. lanuginosum in continental South America although this species has been reported in Central and North America, the Galapagos and several Caribbean islands (Wetterer, 2010b).

Third, Ca. obscurior was noted only during tree baiting (Table 1). Native to Southeast Asia, this species is widespread in the Tropics and Subtropics (Seifert, 2003). Note that the other Cardiocondyla species recorded, $\mathrm{Ca}$. minutior and $\mathrm{Ca}$. wroughtoni (Table 1 and Supplementary Appendix B), both native to the Indo-Malayan region, are tramp species widespread in the Tropics and Subtropics but not yet reported as invasive (Seifert, 2003; Wetterer, 2014b).

Fourth, Tec. vitiensis and Ph. megacephala were only found on trees bearing $A$. aquilega. Already noted in the French Guianese forest, Tc. vitiensis is a wide-ranging invasive species likely native to Southeast Asia whose colony growth is favored by colony fission into many nests and by the presence of reproductive worker-queen intercasts in addition to typical queens (Bolton, 2007; Delabie et al., 2011). Native to Africa, Ph. megacephala is one of the most widespread invasive ants; its huge supercolonies have a massively devastating effect on the native insect fauna (Holway et al., 2002; Wetterer, 2012).

Therefore, A. aquilega baiting provides new information on the presence of invasive ant species as two such species were found only in this way in the present study. Furthermore, of the 12 invasive species noted in total, five were collected by baiting A. aquilega and were at a density high enough to show that there is a significant concentration of these species in association with this plant (Fig. 2).

One can note that many invasive ants are ground-nesters, so that A. aquilega might be considered inadequate for sheltering colonies of such species. Yet, this is not the case; for example, Ph. megacephala, which is mostly a ground-nester, was noted only by baiting A. aquilega and not in the other situations tested (Table 1 and Appendices A and B). This might be due to the fact that three native invasive species, S. saevissima, S. geminata and W. auropunctata, are present in all human-disturbed areas, rendering it difficult for an imported species (in this case, Ph. megacephala) to establish itself. The few native species able to nest in their presence have adapted to the situation through the use of submissive behaviors and defensive chemicals (Grangier et al., 2007; Roux et al., 2013; Dejean et al., 2015). Nevertheless, Pa. longicornis and Ta. melanocephala avoid the pressure from these three native, invasive species thanks to their ecological preferences as they mostly nest in direct contact or inside human constructions (Wetterer, 2008, 2009).

\section{Conclusion}

This survey, mostly conducted in cities where introduced invasive ants are known to nest before spreading to slightly humandisturbed and then undisturbed natural areas (Holway et al., 2002), has highlighted the complementarity between baiting ants on the ground and on urban trees, particularly those bearing $A$. aquilega clusters. Because A. aquilega 'concentrates' certain invasive ants, this global strategy will likely permit researchers to record as exhaustively as possible introduced invasive ants in the areas studied before these ants spread. It appears, therefore, that baiting surveys aiming to detect invasive ant presence in Neotropical cities need to take into account the complementarity between detecting invasive ant species presence on the ground and on trees, particularly those bearing large tank bromeliads and other epiphytes.

\section{Acknowledgments}

We are grateful to Andrea Yockey-Dejean for proofreading the manuscript, Alexis Carteron and Frédéric Azémar for technical help, the Laboratoire Environnement de Petit Saut for furnishing logistical assistance, and the municipality of Sinnamary (through the Department of the Environment) for permitting us to work inside the city limits. Financial support for this study was provided by an 'Investissement d'Avenir' grant managed by the French Agence Nationale de la Recherche (CEBA, ref. ANR-10-LABX-0025). ST's financial support was provided by a PhD fellowship from the Université Antilles-Guyane, ASL and OD's financial support was provided by a PhD fellowship from the French Centre National de la Recherche Scientifique (CNRS) and the Fond Social Européen (FSE). JHCD acknowledges his research grant from CNPq.

\section{Appendix A. Supplementary data}

Supplementary data associated with this article can be found, in the online version, at http://dx.doi.org/10.1016/j.ecolind.2015. 05.027

\section{References}

Addison, P., Samways, M.J., 2006. Surrogate habitats demonstrate the invasion potential of the African pugnacious ant. Biodivers. Conserv. 15, 411-428.

Blüthgen, N., Verhaagh, M., Goitía, W., Blüthgen, N., 2000. Ant nests in tank bromeliads. An example of non-specific interaction. Insect. Soc. 47, 313-316.

Bolton, B., 2007. Taxonomy of the dolichoderine ant genus Technomyrmex Mayr (Hymenoptera, Formicidae) based on the worker caste. Contr. Am. Entomol. Inst. 35, 1-150.

Cach-Pérez, M.J., Andrade, J.L., Chilpa-Galván, N., Tamayo-Chim, M., Orellana, R., Reyes-García, C., 2013. Climatic and structural factors influencing epiphytic bromeliad community assemblage along a gradient of water-limited environments in the Yucatan Peninsula, Mexico. Trop. Conserv. Sci. 6, 283-302.

Carrias, J.F., Céréghino, R., Brouard, O., Pélozuelo, L., Dejean, A., Couté, A., Corbara, B., Leroy, C., 2014. Two coexisting tank-bromeliads host distinct algal communities on a tropical inselberg. Plant Biol. 16, 997-1004.

Clavero, M., Garcia-Berthou, E., 2005. Invasive species are a leading cause of animal extinctions. Trends Ecol. Evol. 20, 110.

Conceição, E.S., Delabie, J.H.C., Della Lucia, T.M.C., Costa Neto, A.O., Majer, J.D., 2014 Structural changes in arboreal ant assemblages (Hymenoptera: Formicidae) in an age sequence of cocoa plantations in the south-east of Bahia, Brazil. Aust. Ecol., http://dx.doi.org/10.1111/aen.12128

Davidson, D.W., Epstein, W.W., 1989. Epiphytic associations with ants. In: Lüttge, U. (Ed.), Vascular Plants as Epiphytes. Springer-Verlag, New York, pp. 200-233, 270.

Dejean, A., 1990. Influence de l'environnement préimaginal et précoce dans le choix du site de nidification de Pachycondyla (=Neoponera) villosa Fabr. (Formicidae, Ponerinae). Behav. Proc. 21, 107-125.

Dejean, A., Corbara, B., Carpenter, J.M., 1998. Nesting site selection by wasps in the Guianese rain forest. Insect. Soc. 45, 33-41.

Dejean, A., Corbara, B., Céréghino, R., Leponce, M., Roux, O., Rossi, V., Delabie, J.H.C., Compin, A., 2015. Traits allowing some ant species to nest syntopically with the fire ant Solenopsis saevissima in its native range. Insect Sci., http://dx.doi.org/10. $1111 / 1744-7917.12078$

Dejean, A., Olmsted, I., Snelling, R.R., 1995. Tree-epiphyte-ant relationships in the low inundated forest of Sian Ka'an Biosphere Reserve, Quintana Roo, Mexico. Biotropica, 57-70.

Delabie, J.H.C., Groc, S., Dejean, A., 2011. The tramp ant Technomyrmex vitiensis (Hymenoptera: Formicidae: Dolichoderinae) on South America. Fla. Entomol 94, 688-689.

Delabie, J.H.C., Nascimento, I.C., Pacheco, P., Casimiro, A.B., 1995. Community structure of house-infesting ants in southern Bahia, Brazil (Hymenoptera Formicidae). Fla. Entomol. 78, 264-270. 
Djiéto-Lordon, C., Dejean, A., 1999. Tropical arboreal ant mosaic: innate attraction and imprinting determine nesting site selection in dominant ants. Behav. Ecol. Sociobiol. 45, 219-225.

Gibernau, M., Orivel, J., Delabie, J.H.C., Barabé, D., Dejean, A., 2007. An asymmetrical relationship between an arboreal ponerine ant and a trash-basket epiphyte (Araceae). Biol. J. Linn. Soc. 91, 341-346.

Givnish, T.J., Barfuss, M.H.J., Van Ee, B., Riina, R., Schulte, K., Horres, R., Gonsiska, P.A., Jabaily, R.S., Crayn, D.M., Smith, J.A.C., Winter, K., Brown, G.K., Evans, T.M. Holst, B.K., Luther, H., Till, W., Zizka, G., Berry, P.E., Sytsma, K.J., 2011. Adaptive radiation and diversification in Bromeliaceae: insights from a 7-locus plastid phylogeny. Am. J. Bot. 98, 872-895.

Grangier, J., Le Breton, J., Dejean, A., Orivel, J., 2007. Coexistence between dominant populations of Wasmannia auropunctata and Cyphomyrmex ants. Behav. Proc. 74, 93-96.

Holway, D.A., Lach, L., Suarez, A.V., Tsutui, N.D., Case, T.J., 2002. The causes and consequences of ant invasions. Annu. Rev. Ecol. Syst. 33, 181-233.

Laurance, W.F., Goosem, M., Laurance, S.G.W., 2009. Impacts of roads and linear clearings on tropical forests. Trends Ecol. Evol. 24, 659-669.

LeBrun, E.G., Jones, N.T., Gilber, L.E., 2014. Chemical warfare among invaders: a detoxification interaction facilitates an ant invasion. Science 343, 1014-1017.

Lenoir, A., Devers, S., Touchard, A., Dejean, A., 2015. The Guianese population of the fire ant Solenopsis saevissima is unicolonial. Insect Sci. (in press).

MacGown, J.A., Boudinot, B., Deyrup, M., Sorger, D.M., 2014. A review of the Nearctic Odontomachus (Hymenoptera: Formicidae: Ponerinae) with a treatment of the males. Zootaxa 3802, 515-552.

Moffett, M.W., 2012. Supercolonies of billions in an invasive ant: what is a society? Behav. Ecol. 23, 925-933.

Mori, S.A., Cremers, G., Gracie, C., de Granville, J.-J., Hoff, M., Mitchell, J.D., 1997. Guide to the vascular plants of central French Guiana. Mem. N. Y. Bot. Gard. 76, $1-442$.

R Core Team, 2013. R: A Language and Environment for Statistical Computing R Foundation for Statistical Computing, Vienna, Austria, URL: http://www.Rproject.org/

Orivel, J., Grangier, J., Foucaud, J., Le Breton, J., Andrès, F.X., Jourdan, H., Delabie J.H.C., Fournier, D., Cerdan, P., Facon, B., Estoup, A., Dejean, A., 2009. Ecologically heterogeneous populations of the invasive ant Wasmannia auropunctata within its native and introduced ranges. Ecol. Entomol. 34, 504-512.

Richardson, B.A., Richardson, M.J., Scatena, F.N., McDowell, W.H., 2000. Effects of nutrient availability and other elevational changes on bromeliad populations and their invertebrate communities in a humid tropical forest in Puerto Rico. J Trop. Ecol. 16, 167-188.

Roux, O., Rossi, V., Céréghino, R., Compin, A., Martin, J.-M., Dejean, A., 2013. How to coexist with fire ants: the roles of behaviour and cuticular compounds. Behav. Proc. 98, 51-57.

Sarkar, D., 2008. Lattice: Multivariate Data Visualization with R. Springer, Berlin Heidelberg, pp. 273

Seifert, B., 2003. The ant genus Cardiocondyla (Insecta: Hymenoptera: Formicidae) a taxonomic revision of the C. elegans, C. bulgarica, C. batesii, C. nuda, C. shuckardi, C. stambuloffii, C. wroughtonii, C. emeryi, and C. minutior species groups. Ann. Naturhist. Mus. Wien 104B, 203-338.

Serramo Lopez, L.C., Da Nóbrega Alves, R.R., Rios, R.I., 2009. Micro-environmental factors and the endemism of bromeliad aquatic fauna. Hydrobiologia 625 151-156.

Shogren, J.F., Tschirhart, J., 2005. Integrating ecology and economics to address bioinvasions. Ecol. Econ. 52, 267-271.

Taber, S.W., 2000. Fire Ants. Texas A\&M University Press, College Station, pp. 308

Warman, L.D., Forsyth, D.M., Sinclair, A.R.E., Freemark, K., Moore, H.D., Barrett, T.W. Pressey, R.L., White, D., 2004. Species distributions, surrogacy, and important conservation regions in Canada. Ecol. Lett. 7, 374-379.

Wenzel, J.W., 1996. Learning, behavior programs, and higher-level rules in nest construction of Polistes. In: Turillazzi, S., West-Eberhard, M.J. (Eds.), Natural History and Evolution of Paper-Wasps. Oxford University Press, Oxford, pp. 58-74, 414

Wetterer, J.K., 2008. Worldwide spread of the longhorn crazy ant, Paratrechina longicornis (Hymenoptera: Formicidae). Myrmecol. News 11, 137-149.

Wetterer, J.K., 2009. Worldwide spread of the ghost ant, Tapinoma melanocephalum (Hymenoptera: Formicidae). Myrmecol. News 12, 23-33.

Wetterer, J.K., 2010a. Worldwide spread of the flower ant, Monomorium floricold (Hymenoptera: Formicidae). Myrmecol. News 13, 19-27.

Wetterer, J.K., 2010b. Worldwide spread of the wooly ant, Tetramorium lanuginosum (Hymenoptera: Formicidae). Myrmecol. News 13, 81-88.

Wetterer, J.K., 2012. Worldwide spread of the African big-headed ant, Pheidole megacephala (Hymenoptera: Formicidae). Myrmecol. News 17, 51-62.

Wetterer, J.K., 2014a. A South American fire ant, Solenopsis nr. saevissima, in Guadeloupe, French West Indies. Biol. Invas. 16, 755-758.

Wetterer, J.K., 2014b. Worldwide spread of the lesser sneaking ant, Cardiocondyla minutior (Hymenoptera: Formicidae). Fla. Entomol. 97, 567-574.

Wetterer, J.K., Wetterer, A.L., 2004. Ants (Hymenoptera: Formicidae) of Bermuda. Fla. Entomol. 87, 212-221. 